
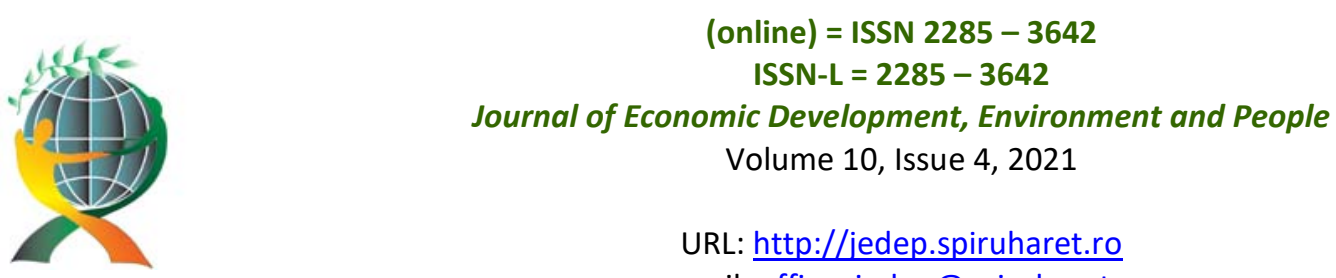

URL: http://jedep.spiruharet.ro e-mail: office jedep@spiruharet.ro

\title{
The Effect of Promotion on Impulsive Buying with Lifestyle as a Moderatio Variable on Fashion Products in Online Shop Shopee
}

\author{
lin Widyastuty ${ }^{1}$ \\ Dhian Tyas Untari ${ }^{2}$ \\ ${ }^{1}$ Student of Magister Management, Faculty of Business and Economic, \\ University of Bhayangkara Jakarta University \\ ${ }^{2}$ Lecturer of Magister Management, Faculty of Business and Economic, \\ University of Bhayangkara Jakarta University
}

\begin{abstract}
The purpose of this study was to explain the effect of promotion on impulsive buyers and to explain that people with high lifestyles often make impulse purchases. Sampling using incidental sampling technique, the number of respondents as many as 100 respondents. The data collection method used is the observation method and the questionnaire method. Analysis of the data used is a multiple linear regression analysis with moderating variables using the SPSS program. The results of the study prove that promotion has a direct effect on impulse buying and it is not proven that people with a high lifestyle are more likely to make impulsive purchases.
\end{abstract}

Keywords: impulsive buying, promotion, lifestyle, online shop

JEL Codes: M31

How to cite: Untari, D., \& Widyastuty, I. (2021). The Effect of Promotion on Impulsive Buying with Lifestyle as a Moderation Variable on Fashion Products in Online Shop SHOPEE. Journal of Economic Development, Environment and People, 10(4), 5-9. doi: http://dx.doi.org/10.26458/iedep.v10i4.710

\section{Introduction}

The high level of internet use has a significant impact on people's shopping patterns. Nowadays people easily shop without having to travel. Only by bringing a cellphone, someone is free to surf from one marketplace to another to get the products they need (Ali et al, 2019).

\footnotetext{
+ Corresponding author: e-mail address: tyas un@yahoo.co.id
} 
Even today, technological advances can affect people's shopping behavior, were not only looking for needed items but often intense promotions can influence someone to buy something that may not even be needed (Dharmanto et al, 2019).

Interesting consumer behavior in modern retail stores is the existence of impulse buying behavior or what is commonly called marketers with unplanned purchases. Impulse buying can be interpreted as part of a condition called "unplanned purchase" or unplanned purchases (Purwa \& Yasa, 2014). According to Mowen and Minor (2002), impulse buying is related to buying actions that are not consciously recognized as a result of consideration or buying intentions that are formed before entering the store.

The majority of consumers who make impulse purchases buy spontaneously, do not think about the consequences, and are influenced by emotional conditions. According to Saladin and Oesman (2002) promotion is related to the communication of information between sellers and buyers which aims to change the attitudes and behavior of buyers, who previously did not know to become familiar so that they become buyers and remember the product.

The understanding of impulse buying is now beginning to be mapped out by marketers well, it can be seen by the increasing number of shops or shopping centers or other producers and marketers who provide many offers for their (prospective) consumers, including through promotional programs. So this affects the buying patterns of consumers, who indirectly have made impulse purchases just because they are interested in the promotions offered by marketers.

One of the most famous marketplaces in Bekasi is Shopee. Several studies state that Shopee has many advantages including lower prices, many discounts, and a large variety of products. In addition, the goods tracking system that is very easy to understand by users increasingly makes Shopee superior among other market places. Thus, the purpose of the study is to find out whether promotion has an effect on impulsive buying and find out whether lifestyle can affect someone's impulsive buying pattern.

\section{Methodology}

The respondents involved in the study were 100 people who are active users of the Shopee Online Shop who are located in Bekasi. The sampling technique in this study was using the Non Probability Sampling technique, namely the Incidental Sampling technique (Sudarmanto, 2005). The research variable in this research is Promotion $(\mathrm{X})$ with sales promotion and advertising indicators. Moderation Variable ( $\mathrm{Z}$ ) with high lifestyle indicator and ordinary lifestyle. Impulse buying variable (Y) with spontaneous indicators, without thinking of consequences, in a hurry, and influenced by emotional states. Data collection methods used in this study were questionnaire, interview, observation, and documentation methods. The data analysis technique used descriptive percentage analysis and multiple regression analysis.

Based on the description above, hypotheses and research models can be formulated as follows:

H1: Promotion has a direct effect on impulse buying.

H2: People with a high lifestyle are more likely to make impulse purchases. 

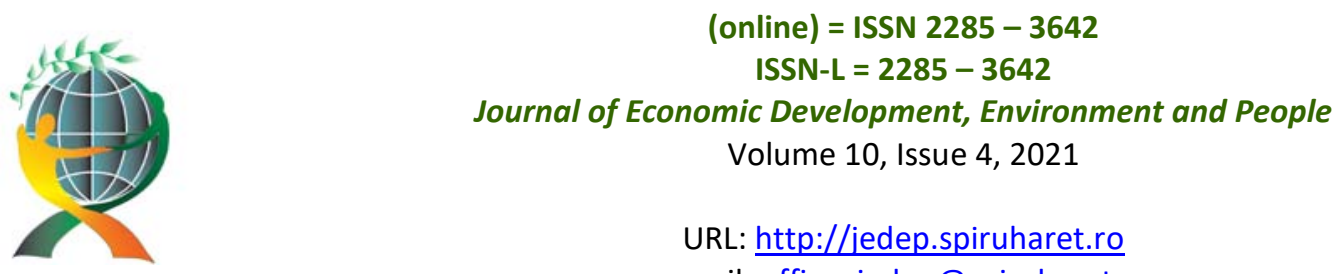

URL: http://jedep.spiruharet.ro e-mail: office jedep@spiruharet.ro

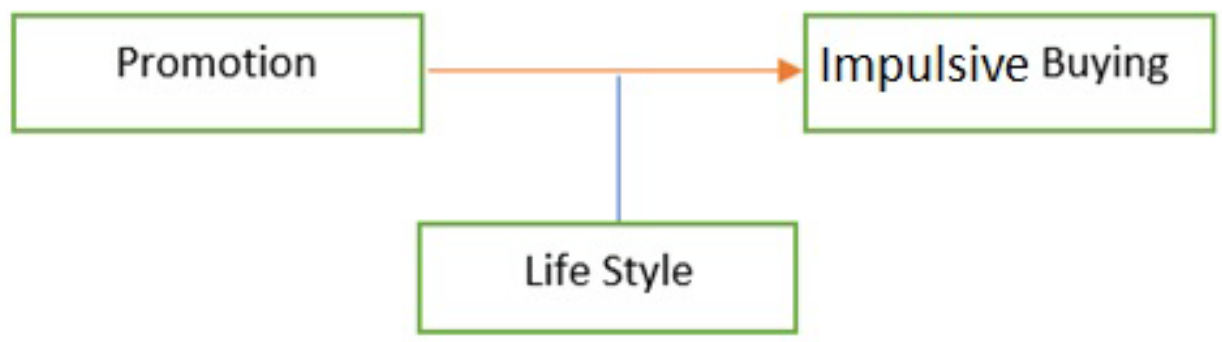

Figure 1. Research framework

\section{Results and discussions}

The results of the validity test for the seven promotional variable statement items can be concluded that all the question items used to measure the product promotion variable are valid. Likewise, the validity test on the 6 items of the impulsive variable questions were all declared valid. The results of the reliability test for the promotion and impulse buying variables can be explained that the value of Cronbrach's alpha count is above 0.70 , this shows that all variables in this study can be declared reliable (Susetyo, 2012).

To test the hypothesis can be done by using a partial test $(t)$. to find out how far the influence of the explanatory variable can explain the dependent variable. The results of the partial test $(t)$ can be seen in the SPSS output table in table 1 below,

Table 1. Output SPSS

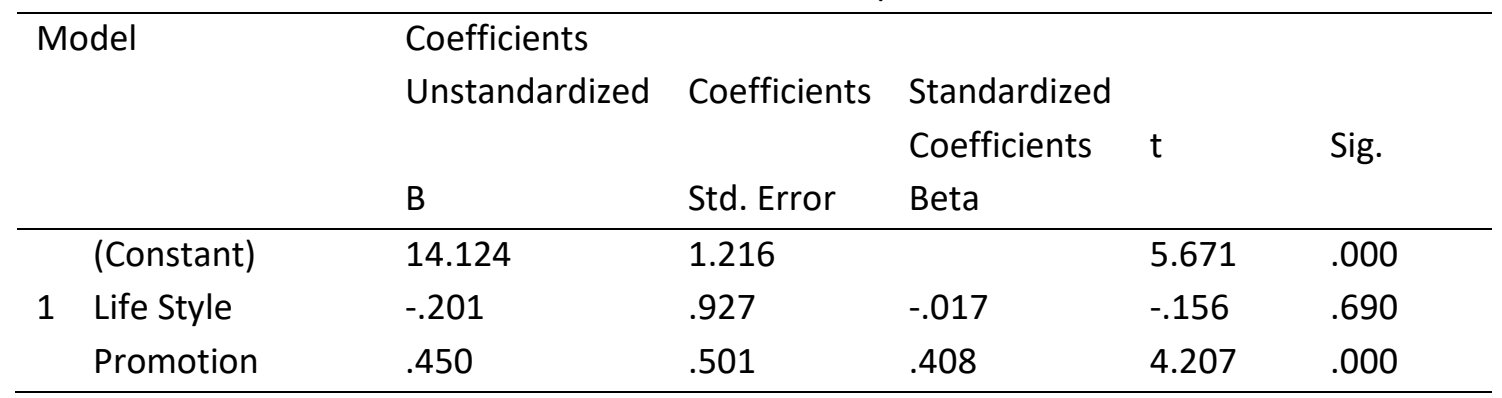

Source: processed data, 2021 
Based on Table 1, the Promotion variable obtained a $t$-count value of 5,671 with a significance level of $0.000<0.05$, this means that $\mathrm{H} 1$ Promotion has a direct effect on impulsive purchases on purchasing fashion products at Shopee Online Shop. It can be explained that promotion has an effect on impulse buying through two indicators, namely sales promotion and advertising. Based on the results of respondents' answers, the indicator that has the lowest influence is advertising, meaning that the community is more affected by sales promotions such as discounts and promos in the form of buying one get one free compared to only seeing advertisements that often appear in the inbox of Shopee online shop users.

In addition, for the lifestyle variable, the t-count value is -0.156 with a significance level of 0.690 $>0.05$. This means that $\mathrm{H} 2$ people with high lifestyles are more likely to make impulse purchases. It can be explained that lifestyle has no effect on impulse buying through two indicators, namely high lifestyle and ordinary lifestyle. This shows that promotional abilities can influence everyone with various lifestyles to make impulsive buying.

\section{Conclusions}

To increase impulse purchases made by consumers of fashion products at Shopee online shops, companies and marketers should increase promotions on sales promotion indicators by providing special discounts for loyal consumers, so that buyers feel special and increase the bonding between marketers and consumers. In addition, marketers can provide more attractive prizes on point redemption so that consumers are stimulated to make more massive impulse purchases.

\section{References}

Ali, S., Maharani, L., Untari, D.T. 2019. Development of religious tourism in Bandar Lampung, Indonesia African Journal of Hospitality, Tourism and Leisure, 2019, 8(5)

Dharmanto, A., Komariah, N.S., Handayani, M., Suminar, R., Untari, D.T. 2019. Analysis of tourism preferences in choosing online-base travel agents in Indonesia International Journal of Scientific and Technology Research, 2019, 8(12), pp. 3761-3763

Mowen, John C dan Michael Minor. 2002. Perilaku Konsumen, jilid 1 edisi kelima.Jakarta: Penerbit Erlangga.

Purwa, E. M. R. G \& Yasa, N. N. K. 2014. Strategi Store Environment Dan Time Pressure pada Pembelian Impulsif Melalui Emotional State. Jurnal Dinamika Manajemen. 5 (2)

Saladin, Djaslim dan Oesman, Yevis Marty. 2002. Perilaku Konsumen dan Pemasaran Strategik. Jakarta: Balai Pustaka

Susetyo, Budi. 2012. Statistika untuk Analisis Data Penelitian. Bandung: PT Cakra.

Sudarmanto, Gunawan. 2005. Analisis Regresi Linear Ganda dengan SPSS. Yogyakarta: Graha Ilmu. 